УДК 373.67

DOI:

Ольга Черсак, доцент кафедри методики музичного виховання та диригування ДВНЗ “Прикарпатський національний університет імені Василя Стефаника”, заслужена артистка України

Ольга Молодій, доцент кафедри методики музичного виховання та диригування ДВНЗ “Прикарпатський національний університет імені Василя Стефаника”, заслужена артистка України

\title{
РОЗВИТОК МУЗИЧНО-ТВОРЧИХ ЗДІБНОСТЕЙ УЧНІВ ПОЧАТКОВОЇ ШКОЛИ НА УРОКАХ МУЗИЧНОГО МИСТЕЦТВА
}

Стаття присвячена проблемі розвитку музично-творчих здібностей учнів початкової школи на уроках музичного мистецтва. Сьогодні активно відбуваються реформи у сфері освіти, метою яких є формування конкурентоздатної, творчої особистості, котра спроможна до самовизначення, самореалізації та самовдосконалення; сприяти ї̈ всебічному розвитку, талантів, здібностей, компетентностей, творчості й допитливості. Саме тому сучасна школа повинна забезпечити становлення такої особистості, а важливу роль у реалізації цихх завдань необхідно надати музичному мистецтвву.

Розкрито сутність поняття “музично-творчі здібності”. Стверджується, шуо всі діти народжуються із задатками для формування музичних здібностей, які згодом успішно реалізовуються у процесі навчання та виховання і сприяють гармонійному розвитку особистості.

Ключові слова: творча діяльність; молодиі школярі; музичні твори; гармонійний розвиток; імпровізачія.

תim. 9.

Olga Chersak, Associate Professor of the Methods of Music Education and Conducting Department State Higher Educational Institution "Vasyl Stefanyk Precarpathian National University"

Honored Artist of Ukraine

Olga Molodiy, Associate Professor of the Methods of Music Education and Conducting Department State Higher Educational Institution "Vasyl Stefanyk Precarpathian National University"

Honored Artist of Ukraine

\section{DEVELOPMENT OF MUSICALAND CREATIVE ABILITIES OF PRIMARY SCHOOL STUDENTS IN THE LESSONS OF MUSIC ART}

The article is devoted to the problem of developing musical and creative abilities of primary school students in music lessons. After all, reforms in the field of education are currently underway, the aim of which is to form a competitive, creative personality that is capable of self-determination, self-realization and self-improvement; to promote its comprehensive development, talents, abilities, competencies, creativity and curiosity. That is why the modern school should ensure the formation of such a personality, and an important role in solving these problems should be given to the art of music.

The essence of the concept "musical and creative abilities" is revealed. It is found that all children are born with the makings for the formation of musical abilities, which are then successfully implemented in the process of learning and education and contribute to the harmonious development of personality.

The authors substantiate the theoretical aspects of musical and creative abilities development of primary school students in the process of musical improvisation in music lessons. It is proved that improvisation plays an important role in the development of musical and creative abilities of students, in particular musical improvisation, which is a special kind of creativity in which melodies / intonations / is created directly in the process of performance.

It is concluded that children of primary school age need to develop the ability to creatively perceive music and experience musical images; the ability to feel the character and mood of a piece of music; listen, compare, evaluate the brightest means of musical expression; feel the emotional expressiveness of pitch. It is expedient for the teacher to make a creative microclimate in music lessons, emotional and figurative problem situations close in content to the children's life needs and interests.

Keywords: creative activity; primary school students; musical works; harmonious development; improvisation.

П остановка проблеми. Завдання, які постали перед сучасним суспільством, зумовлюють постійне вдосконалення освітніх систем, створення умов для розвитку та самореалізації кожної особистості, здатної навчатися упродовж життя. Відомо, що в різні історичні епохи ставлення суспільства до освіти змінювалося, але завжди ¥ї вважали 
пріоритетною у формуванні творчої особистості.

Нині активно відбуваються реформи у сфері освіти, метою яких є формування конкурентоздатної, творчої особистості, котра спроможна до самовизначення, самореалізації і самовдосконалення; здатна сприяти іï всебічному розвитку, талантів, здібностей, компетентностей, творчості та допитливості. Саме тому сучасна школа повинна забезпечити становлення такої особистості, а важливу роль у розв'язанні цих завдань варто надати музичному мистецтву.

Як показує досвід, музика в початковій школі сприяє формуванню гуманістично орієнтованої особистості, розвитку піi творчих здібностей і талантів.

Аналіз останніх досліджень і публікацій. Наукові розвідки засвідчують, що питанню розвитку музичних здібностей присвячена значна кількість праць у галузях педагогіки, психології та філософії. Проблема розвитку музичних здібностей особистості викликає особливий інтерес психолого-педагогічної науки, оскільки відомості про природу цього унікального явища необхідні для створення системи виховання i навчання учнів, сприяння розвитку їхнього творчого потенціалу. Так, шляхи розвитку музично-творчих та музичних здібностей досліджували А. Арісменді, Е. Башич, П. Вейс, В. Верховинець, Д. Кабалевський, М. Леонтович, К. Орф, К. Стеценко та інші. Роль навчання в розвитку музичних здібностей, можливостей і закономірностей їх формування вивчали вчені С. Алмазов, А. Варламов, Л. Венгер, Н. Ветлугіна, А. Катинене, В. Крутецький, А. Ларіонова, А. Маслова, В. Морозов, Н. Орлова, Г. Ревеш, М. Румер, Б. Теплов, В. Шацька, Б. Яворський та ін.

Проблема розвитку музичних здібностей розглядалася в сучасних дослідженнях Т. Дорошенко, О. Лобової, Р. Савченко, О. Хижної та ін. Музична імпровізація була предметом вивчення педагогівмузикантів. Так, у музичній педагогіці й навчальній практиці іiі передусім досліджували та використовували як засіб виховання дітей (Б. Асаф'єв, П. Вейс, Е. Жак-Далькроз, Д. Кабалевський,Б. Теплов, В. Шацька, Б. Яворський); засіб виховання творчої індивідуальності (К. Шпаковська); засіб розвитку творчих якостей і здібностей учнів (К. Орф, Н. Зенкіна, І. Золотова, О. Винокурова); ефективний спосіб розвитку креативності (Т. Дмитрієва); ефективну форму роботи, що забезпечує успішне формування й удосконалення виконавськихуміньтанавичок(С.Олійник,С.Степанова, Н. Сродних, В. Усачова). Особливостям навчання джазової імпровізації приділяли увагу такі педагоги, як Д. Бейкер, І. Бриль, Дж. Мехіган, Дж. Кокер, Ю. Козирьов, Ю. Маркін, Дж. Рассел, О. Степурко.

Мета статті полягає у теоретичному обгрунтуванні розвитку музично-творчих здібностей учнів початкової школи в процесі музичної імпровізації.

Виклад основного матеріалу. Молодший шкільний вік є важливим періодом у загальному розвитку дитини, який впливає на подальше формування іiї фізичних, розумових та творчих здібностей. Типовимипсихологічними особливостями молодших школярів є піддатливість, пластичність, чутливість, емоційність, образність мислення, які створюють найсприятливіші умови для розвитку естетичного ставлення до навколишнього світу, музики. Саме за цього періоду закладається основа для підготовки дітей до творчої праці. У цьому віці розвиваються уява, творче мислення, виховується допитливість, спостережливість, уміння аналізувати, порівнювати, узагальнювати факти, робити висновки.

Видатний педагог В. Сухомлинський стверджував, що жодний широкий розмах естетичного виховання в старших класах не може компенсувати те, що пропущено в ранньому віці. "Учень - не посудина, яку треба наповнити, а факел, який треба запалити", - наголошував педагог [8, 54]. 3 перших днів навчання школа покликана виховувати в учнів потяг до всього прекрасного в житті, розвивати в них естетичне, образне сприйняття світу, творчу здібність бачити й чути, відчувати й запам'ятовувати, спостерігати й фантазувати.

У контексті досліджуваної проблеми важливими є музичні здібності учнів початкової школи. Як свідчить аналіз наукової літератури, проблема здібностей - одна 3 найбільш дискусійних і актуальних у сучасній педагогіці та психології. У традиційному розумінні здібності базуються на індивідуальнопсихологічних якостях особистості i $\epsilon$ передумовою успішного виконання нею певного виду діяльності (театральної, музичної, художньої, хореографічної тощо). Ми погоджуємося 3 міркуваннями учених $[1 ; 2 ; 5 ; 6]$ про те, що всі діти народжуються із задатками для формування музичних здібностей, які згодом успішно реалізовуються в процесі навчання та виховання і сприяють гармонійному розвитку особистості.

Гармонійному творчому розвитку учнів сприяють усі навчальні дисципліни, проте найбільші можливості для цього відкриваються на уроках естетичного циклу, зокрема, музичного мистецтва, основним завданням якого $є$ відчуття 


\section{РОЗВИТОК МУЗИЧНО-ТВОРЧИХ ЗДІБНОСТЕЙ УЧНІВ ПОЧАТКОВОЇ ШКОЛИ НА УРОКАХ МУЗИЧНОГО МИСТЕЦТВА}

школярами радості від творчості, бо з нею пов'язана емоційна чутливість. В. Сухомлинський писав: “Не можна відгороджувати дітей від оточуючого світу кам'яною стіною. Не можна позбавляти учня радісного духовного життя. Духовне життя людиниповноцінне лише тоді, коли вона живе в світі гри, казки, музики, фантазії, творчості. Без цього вона - засушена квітка" [7, 67-68].

Уважаємо, що важливу роль у формуванні творчості учнів має імпровізація, зокрема музична. Музична імпровізація “це особливий вид елементарної творчості, при якому мелодії (інтонації) створюються безпосередньо в процесі виконання. В умовах музичної імпровізації школярі можуть найбільш повно розкривати творчі можливості, поєднувати в єдиний процес елементарні здібності композитора і виконавця.

Наукові розвідки дають підстави стверджувати, що поняття “імпровізація” включає в себе, з одного боку, непідготовлене виконання творів експромтом (тобто нового твору, що є миттєвим втіленням, що виникають у виконавця), а з іншого - видозміни, варіювання, доповнення й узагальнення композицій які вже існували, поза залежністю від того, чи записані вони повністю нотами, чи тільки приблизно намічені. Імпровізація - це “не просто поєднання композитора з виконавцем, а специфічна здатність з блискавичною реакцією поєднувати духовні й моторні компоненти в єдиний загальний плин, єдину структуру, яка показує нову якість" $[3,96]$.

В імпровізаційній діяльності важливий не тільки результат, але і безпосередній творчий процес, у якому розвиваються здібності й формуються творчі якості особистості.

Імпровізація-найдавніший і найдемократичніший вид музичного мистецтва, який існував протягом віків [4, 206]. Імпровізація була основою творчості виконавця. Імпровізувати, а значить розвивати свої творчі нахили, здатна практично кожна дитина. Загальноосвітня школа має для цього необмежені можливості. Тут застосовуються найрізноманітніші форми і методи навчання.

Залучення учнів до музичної імпровізації та закріплення основних творчих знань і вмінь складна багаторівнева діяльність. Умовно можна розділити їі на чотири рівні. Рівні творчої діяльності, динамічно розвиваючись, охоплюють весь період навчання музично-творчої імпровізації учнів:

І рівень - співтворча діяльність;

II рівень - колективно-індивідуальна творчість;

III рівень - колективне музикування;

IV рівень - індивідуальна творчість.
Кожний рівень домінує на певному етапі творчого розвитку, але може включати i попередній, і елементи наступного.

Актуалізуючи загальнодидактичні принципи навчання дітей імпровізації, учитель повинен стежити, щоб музично-творчі завдання відповідали таким основним педагогічним вимогам:

- високохудожності, з опорою на народний i дитячий фольклор;

- проблемності та варіативності;

- взаємозв'язку навчання, виховання та розвитку;

- доступності та врахування вікових особливостей школярів;

- взаємозв'язку музичного, літературного та художнього матеріалу з важливими подіями країни та життєвими ситуаціями школярів;

- тематичній єдності всіх видів творчої діяльності;

- самостійності в розв'язанні емоційнообразних ситуацій, творчих завдань;

- наочності музично-ілюстративного матеріалу;

- колективному характеру навчання 3 урахуванням індивідуальних особливостей дітей.

На початкових стадіях заохочення до творчої діяльності учнів найбільш ефективним способом впливу є показ імпровізаційного розв'язання створюваної вчителем емоційно-образної ситуації під час аргументованого пояснення або проблемного викладу. Показ результату творчої діяльності $є$ послідовним поясненням учням безпосереднього процесу імпровізації. Учителеві бажано розповісти та проілюструвати школярам можливі творчі підходи та варіанти розв'язання завдання. До прикладу, педагог сам ставить перед собою завдання і сам його виконує, разом iз дітьми аналізує основні моменти імпровізації. У подальшому акцент активності поступово переноситься на діяльність учнів.

Кожне творче завдання залежно від змісту має бути виконане такими різними за характером та видом імпровізаціями:

- імпровізація запитання-відповідь;

- мелодизація віршованого тексту;

- імпровізація на власний текст;

- розгортання та завершення мелодичних зворотів;

- імпровізація “по ланцюжку”;

- добір ритмічного та ладогармонічного акомпанементу;

- імпровізація та музикування на ладогармонічній основі;

- підголосна та імітаційна імпровізація;

- музичні діалоги; 


\section{РОЗВИТОК МУЗИЧНО-ТВОРЧИХ ЗДІБНОСТЕЙ УЧНІВ ПОЧАТКОВОЇ ШКОЛИ НА УРОКАХ МУЗИЧНОГО МИСТЕЦТВА}

- імпровізація та створення твору на теми
емоційно-образної ситуації;
- імпровізація на настрій;
- інсценізування.
У світлі зазначеної проблеми, вважаємо, що в
дітей молодшого шкільного віку необхідно
розвивати здатність до творчого сприйняття
музики і переживання музичних образів; здатність
відчувати характер та настрій музичного твору;
слухати, порівнювати, оцінювати найбільш яскраві
засоби музичної виразності; відчувати емоційну
виразність звуковисотного руху. Щоб в учнів
склалася певна думка про музичний твір, вони
повинні пережити його. “Інакше, ніж емоційним
шляхом,- писав Б. Теплов, - не можна зрозуміти
зміст музики” [9, 51]. Тому вчителю в процесі
бесіди потрібно створити емоційну атмосферу,
активізувати сприймання. Доповнюючи музику
яскравими і образними поясненнями, педагог може
навести доступні для дитини життєві та художні
асоціації, широко використати зіставлення та
порівняння різних творів мистецтва, що дасть змогу
підкреслити різноманітність художніх образів.

Аналіз музичних творів, їх естетична оцінка становлять обов'язковий елемент не тільки слухання музики на уроці, але й інших видів музичної діяльності учнів. Підготовка школярів до сприймання й оцінки творів вимагає вступного слова вчителя. У процесі аналітичного розбору музичних творів діти за керівництва вчителя вчаться зауважувати найдоступніші та найяскравіші виражальні засоби, що розкривають зміст твору, визначати особливості музики, настрої і почуття, якими вона пройнята. Теоретичні знання допомагають пояснити учням особливості музичної мови: мелодії, темпу, сили звучності, звучання регістрів тощо. Розбір музичних творів спонукає дітей зрозуміти особливості музики й водночас усвідомити джерела своїх вражень, ті компоненти музичного матеріалу, які викликають різні асоціації. Щоб в учнів склалася певна думка про музичний твір, вони повинні пережити його. "Інакше, ніж емоційним шляхом, - зазначав Б. Теплов, - не можна зрозуміти зміст музики" [9, 51]. Учена О. Сисоєва слушно зауважує, що розвиток творчих здібностей учнів передбачає цілеспрямоване, науково обгрунтоване конструювання змісту учіння, його дидактичного забезпечення, форм і методів стимулювання творчої навчальної діяльності $[6,111]$.

Набуття учнями здібностей до імпровізаційної діяльності великою мірою залежить від педагогічної майстерності вчителя. По-перше, він завжди повинен підтримувати найменший прояв творчої активності дітей; по-друге, делікатно аналізувати творчі спроби; по-третє, захоплено вчити дітей імпровізувати та своїм настроєм i присутністю підкреслювати естетичну привабливість цієї діяльності. Водночас учителеві в процесі бесіди варто створити емоційну атмосферу, активізувати сприймання. Доповнюючи музику яскравими й образними поясненнями, педагог може навести доступні для дитини життєві та художні асоціації, широко використати зіставлення і порівняння різних творів мистецтва, що уможливить підкреслити різноманітність художніх образів.

Актуалізуючи проблему розвитку музичнотворчих здібностей учнів початкових класів, треба зазначити, що найбільш доцільно використовувати для цього методи ігрової педагогіки. Оскільки загальновідомим є той факт, що ігрова діяльність залишається після навчання провідною формою і в ній розкривається творчий потенціал учнів засобами дидактичних, сюжетно-рольових, предметних ігор. Гра дарує щохвилинну радість, бо під час гри в молодших школярів формуються чи закріплюються властивості, уміння, здібності, необхідні їм для виконання соціальних, професійних, творчих функцій у майбутньому.

Виховні можливості музичного мистецтва надзвичайно великі. Воно допомагає формувати особистість в естетичному, моральному, патріотичному й інших напрямах. Але, як відомо, вплив музики буде ефективним лише в тому випадку, коли школярі матимуть певний рівень духовної культури, досвід спілкування з музичними творами. Інакше найпрекрасніші зразки художньої творчості можуть залишитися незрозумілими та недоступними для них.

Висновки та перспективи подальших досліджень. У науковій літературі відображено різні аспекти проблеми розвитку музично-творчих здібностей учнів початкових класів. На нашу думку, музично-творчі здібності школярів є запорукою успішної музичної діяльності та визначаються як індивідуально-психологічні властивості особистості, адже прагнення до творчого вираження себе в музиці закладене в основі дитячої психіки: бажаючи створити щось “своє”, учень по-своєму опрацьовує отриману інформацію, а метод творчої імпровізації допомагає розвинути естетичний смак учнів та здатність гостріше реагувати на прекрасне.

Учителеві доцільно створювати творчий мікроклімат на уроках музичного мистецтва, емоційно-образні проблемні ситуації, близькі за змістом до дитячих життєвих потреб та інтересів. Важливо формувати в дітей відчуття значущості не тільки результату, але й процесу творчості. 


Актуальним для подальших наукових розвідок
вважаємо розроблення інноваційних методик
розвитку музично-творчих здібностей учнів
початкової школи в різних видах музичної
діяльності.

\section{ЛITЕРАТУРА}

1. Брылин Б. А. Музыкальная импровизация как эстетическая деятельность: Сб. научн. трудов. Кировоград: КГПИ, 1991. С. $101-114$.

2. Горбушко Т. Г. Розвиток творчих здібностей молодших школярів. Початкове навчання та виховання. 2013. № 35-36. С. 15-22.

3. Коган Г. М. Избранные труды. Москва: Просвещение, 1972.159 с.

4. Мальцев С. М. О психологии музыкальной импровизации. Москва: Музыка. 1991. 206 с.

5. Руда Г. С. Розвиток музичних здібностей у дітей молодшого шкільного віку. Науковий часопис Наиіонального педагогічного університету імені М.П. Драгоманова. Серія 16. Творча особистість учителя: проблеми теорії і практики: зб. наук. пр. Київ, 2017. Вип. 29 (39). С. 169-172.

6. Сисоєва С. О. Творчий розвиток учнів у контексті особистісно-орієнтованого навчання. Гуманітарні науки. 2001. №1. С. 110-118.

7. Сухомлинський В.О. Серце віддаю дітям. Вибрані твори: в $5 \mathrm{~m}$. Київ: Радянська школа, 1977. T. 3. $279 \mathrm{c}$.

8. Тарадюк Н. В. Інноваційні технології: креативно-виховний аспект: монографія. Луцьк: Твердиня, 2009. $164 \mathrm{c}$.

9. Теплов Б. М. Проблемы индивидуальных различий. Москва: Изд.-во АПН РСФСР, 1961. $234 \mathrm{c}$.

\section{REFERENCES}

1. Brylin, B.A. (1991). Muzykalnaia improvyzatsyia kak tstetycheskaia deiatelnost [Musical improvisation as an aesthetic activity]. Collection of scientific works. Kirovohrad, pp. 101-114. [in Russian].

2. Horbushko, T. H. (2013). Rozvytok tvorchykh zdibnostei molodshykh shkoliariv [Development of creative abilities of junior schoolchildren]. Primary education and upbringing, No. 35-36, pp.15-22. [in Ukrainian].

3. Kohan, H. M. (1972). Izbrannyie trudy [Selected articles]. Moscov, 159 p. [in Russian].

4. Maltsev, S. M. (1991). O psykhologii muzykalnoi improvizatsyi [About psychologists of musical improvisation]. Moscov, 206 p. [in Russian].

5. Ruda, H. S. (2017). Rozvytok muzychnykh zdibnostei u diteimolodshoho shkilnoho viku[Development of musical abilities in children of primary school age]. Scientific journal of the National Pedagogical University named after M.P. Drahomanov. Series 16. Creative personality of the teacher: problems of theory and practice, Vol. 29(39), pp. 169-172. [in Ukrainian].

6. Sysoieva, S. O. (2001). Tvorchyi rozvytok uchniv u konteksti osobystisno oriientovanoho navchannia [Creative development of students in the context of personality-oriented learning]. Humanities, No.1, pp.110-118. [in Ukrainian].

7. Sukhomlynskyi, V. O. (1977). Sertse viddaiu ditiam [I give my heart to children]. Selected works: in 5 volumes. Kyiv, Vol. 3, 279 p. [in Ukrainian].

8. Taradiuk, N. V. (2009). Innovatsiini tekhnolohii: kreatyvno-vykhovnyi aspect [Innovative technologies: creative and educational aspect]. Lutsk, $164 \mathrm{p}$. [in Ukrainian].

9. Teplov, B. M. (1961). Problemy individualnykh razlichyi [Individual Difference Problems]. Moscov, 234 p. [in Ukrainian].

Стаття надійшла до редакції 10.12.2021

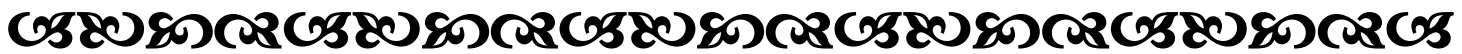

"чим би ви не займалися в житті, робіть ие всім свойм серием".

$$
\begin{array}{r}
\text { Конфууиій } \\
\text { давньокитайський фбілософб }
\end{array}
$$

"Тізнання світу почуттів неможливе без розуміння $і$ переживання музики, без глибоқої духовної потреби слухати ї̈ й діставати насолоду від неї. Без музики важко переқонати людину, яқа вступає у світ, у тому, що людина преқрасна, а це переқонання, по суті, є основою емочійної, естетичної, моральної қультури".

"Музика - уява - бантазія - қазка - твориість - ось доріжка, йдучи якою дитина розвиває свої духовні сили".

Василь Сухомлинський украӥнський педагог, поет

\section{$\cos 8080 \cos 8080 \cos 8080 \cos 80 \operatorname{soc} 638080 \cos$}

